\title{
A SYNTACTIC ANALYSIS OF THE ENGLISH DISCOURSE MARKER ONLY AND ITS VIETNAMESE TRANSLATIONAL EQUIVALENTS
}

\author{
Tran Quoc Thao*,1, Nguyen Van Muoi ${ }^{2}$ \\ ${ }^{1}$ Ho Chi Minh City University of Technology and Education, \\ 01 Vo Van Ngan, Thu Duc, Ho Chi Minh City, Vietnam \\ ${ }^{2}$ Buon Ma Thuot University, 298 Ha Huy Tap, Tan An, Buon Ma Thuot, Vietnam
}

Received 28 April 2016

Revised 09 May 2017; Accepted 16 May 2017

\begin{abstract}
This descriptive and qualitative study, part of a big project, endeavored to explore the syntactic features of the English discourse marker only and its Vietnamese translational equivalents. It involved the development of a bilingual corpus, which consisted of 168 English and 168 Vietnamese instances of sentences containing only. The interpretive contrastive analysis was employed. The findings reveal that only in English often comes in three positions, namely, initial, medial, final, whereas their Vietnamese equivalent usually appears in initial and medial positions. Additionally, there are more similarities than differences in terms of syntactic functions of only used in English and Vietnamese.
\end{abstract}

Keywords: contrastive analysis, discourse marker, English, only, syntactic feature, Vietnamese

\section{Introduction}

The English language, due to its hegemony throughout the world, has become an international language, a lingua franca, or a world language, so it is both the most common language and pivotal tool in international communication and integration. Moreover, much more demand, as a result of rapid globalization and increasing international trade, has been made for people who can communicate orally in English. Language, however, is the quintessence of cultural background. To understand any languages more deeply and clearly, language learners, therefore, should know not only people, customs, cultures, but also the theory of its language to get a thorough insight into the language.

Language, furthermore, is one of the most effectively communicative means which makes everyone become closer and understand each

\footnotetext{
* Corresponding author. Tel.: 84-989637678

Email: thao.tran@hcmute.edu.vn
}

other better. "Faulty communication causes most problems. It leads to confusion and can cause a good plan to fail" (Junarso, 2009, p. 100) since communication is the exchange and flow of information and idea to a receiver. "Effective communication occurs only if the receiver understands the exact information or idea that the sender intended to transmit" (Cochrane \& Pierce, 1988, p. 95). Linguistic meaning, on the other hand, is influenced by and reflects the nature of the relationship between speakers and addresses, the speakers' belief about the addresses' knowledge and state of mind, and the attitude of the speakers.

The word only, like many other discourse markers, poses a wide range of meanings that causes a number of problems since it has different functions in a sentence. It raises the concept of syntactic features which cause a number of problems for non-native speakers as seen in the following examples:

(1) a. Only Carla is holding a balloon.

b. Carla is holding only a balloon. (Matsuoka, 2011, p. 1) 
In (1a) only is employed to premodify a subject and it means "No other person is holding a balloon". Similarly, in (1b) only premodifies an object. It is explained "Carla is holding nothing other than a balloon".

The syntactic position is not always relevant to the interpretation of focus items. In the following example:

(2) a. Kazys gave books only to girls.

b. Kazys gave only books to girls. (Arkadiev, 2010, p. 14)

In (2a), Kazys did not give books to anyone except the girls, but in (2b) No other things are given to the girls but books. Clearly, the position contributes to the interpretation of only, yet it cannot decide differences in reading. In fact, the semantic and pragmatic features will reveal the speaker's idea or thinking more clearly.

The presence of only in the sentence, syntactically, may confuse the readers and hearers because the meaning of the whole sentence largely depends on its position in the sentence. Let us observe the sentences as follows:

(3) a. Only Nancy admires her sister.

b. Nancy only admires her sister.

c. Nancy admires only her sister.

d. Nancy admires her only sister.

e. Nancy admires her sister only.

Sentences, from the abovementioned instances, can be paraphrased differently and convey different meanings when using only in different positions in a sentence, so it is not easy for English learners to use only correctly and properly because only expresses a variety of subtly different meanings and its use is subject to constraints which do not apply to other words with similar meanings. This paper, hence, endeavors to study the discourse marker only in depth in English and in Vietnamese equivalents in order to explore the syntactic features of only in English and its Vietnamese equivalents and their similarities and differences. Two research questions are formed as follows:

1. What are syntactic features of only in English and its Vietnamese equivalents?

2. What are their similarities and differences in terms of syntactic features?

\section{Methodology}

Corpus

A bilingual corpus comprising 168 English and 168 Vietnamese instances of sentences containing only sourced from short stories and modern novels were attained from different literature books and the websites on the Internet. Following is table 1 indicating the corpus for investigation.

Table 1. Bilingual corpus

\begin{tabular}{|c|l|c|c|}
\hline No & \multicolumn{1}{|c|}{ Corpus } & $\begin{array}{c}\text { Sample analysed } \\
\text { (English) }\end{array}$ & $\begin{array}{c}\text { Sample analysed } \\
\text { (Vietnamese) }\end{array}$ \\
\hline 1 & Holiday in the USA & 7 & 7 \\
\hline 2 & Longman Advanced Grammar & 9 & 9 \\
\hline 3 & The Jungle Books & 5 & 5 \\
\hline 4 & The Man of Property & 24 & 9 \\
\hline 5 & The Moon and Sixpence & 9 & 18 \\
\hline 6 & The Old Man and The Sea & 18 & 6 \\
\hline 7 & The Sun also Rises & 6 & 3 \\
\hline 8 & The Sorrow of War & 3 & 7 \\
\hline 9 & The Thorn Birds & 7 & 23 \\
\hline 10 & The International Story & 18 & 18 \\
\hline 11 & 20th Century English Short Stories & 10 & 10 \\
\hline 12 & 20th Century English Short Stories & 10 & 10 \\
\hline 13 & British National Corpus & 19 & 19 \\
\hline 14 & An Introduction to Language & & \\
\hline
\end{tabular}




\section{Research procedure}

This contrastive analysis of the discourse maker only and the Vietnamese translational equivalents is based on the description of its meanings in terms of syntactic features. As regards the data collection, the selected instances must be English as the source language and Vietnamese as the target language, and contain only in English and instances including the actual translational equivalents in Vietnamese. The main sources for collecting data are short stories, modern novels and online text of chat since they may provide with reliable samples written by native writers of English and translated by Vietnamese.

With respect to data analysis, instances containing only and its patterns as discourse markers were classified into meanings and functions in terms of syntactic forms. The discourse marker only and its patterns, then, were qualitatively described and analyzed in terms of syntactic positions and functions.

Double-check was employed in order to increase the reliability of the contrastive analysis. The researchers had two Vietnamese experts, who were both experienced teachers of English and translators, as double-checkers to randomly check three pieces of instances in English and Vietnamese. The two doublecheckers and researchers had to reach to an agreement level of reliability (over $85 \%$ ).

\section{Results and discussion}

\subsection{Positions of only in the sentences and its} Vietnamese equivalents

The discourse marker only can be as a focusing adverb; however, focusing adverbs are not normally used at the beginning of a sentence. The position of only is particularly flexible, conveying slightly different meanings according to where it is placed. There are three main positions for only: initial, medial, and final positions, which is extremely rare with any other adverb.

\section{Initial position}

The adverb is in the initial position in the clause with or without juncture, occurring before the subject or other obligatory elements of the clause. However, in a limited research, this study mentions only only, which modifies not only a noun, a pronoun, but also an adverb of time. Consider the following sentences:

(4) Only the poet or the saint can water an asphalt pavement in the confident anticipation that lilies will reward his labour. (Junarso, 2009, p.46)

Chỉ có nhà thơ hoặc vị thánh mới có thể tưới nước trên con đường tráng nhựa mà dám quả quyết trước là hoa huệ sẽ thưởng công lao động của họ. (Nguyễn Thành Thống, 1987, p.70)

(5) But, he thought, I keep them with precision. Only I have no luck any more. But who knows? Maybe today. Every day is a new day. (Hemingway, 1952, p.24)

Nhưng, lão nghĩ, mình giữ chúng chính xác. Duy chỉ mình không còn may mắn nữa thôi. Nhưng biết đâu được? có thể hôm nay. Mỗi ngày là một ngày mới. (Lê Huy Bắc, 1998, p.28)

It is impossible for us to put only in other positions in above situations. Clearly, when only is placed in the initial position in English and its equivalents in Vietnamese, it has its own meaning, semantic and pragmatic. But unlike the above examples, only in (6) is in the initial position in English, while its equivalent in Vietnamese is placed in a different position as follows:

(6) “That's wonderful." he said sadly, "wonderful" 
"Only he wants me to change the title." "Yes?" (Cochrane \& Pierce, 1988, p.239)

"Thật là tuyệt diệu!" "Anh ta nói buồn bã: "Tuyệt diệu!"

"Ông ta chỉ muốn em đổi tên sách"

"Thế à?" (Mai Khắc Hải \& Mai Khắc Bích, 1994b, p.250)

\section{Medial position}

Only, in this situation, is similarly used as other focusing adverbs. The medial position can be easily identified after the lexical verb and in front of other obligatory element of the clause. For example:

(7) I remember only my own grief and fright and the shiny path over father's head.... (Rooth, 1996, p.83) Tôi chỉ còn nhớ nỗi đau khổ và lo sợ và vệt bóng loáng trên đầu bố tôi.

(8) Then he felt the gentle touch on the line and the happy.

"It was only his turn," he said. "He'll take it”. (Hemingway, 1952, p.34)

Lúc ấy lão cảm thấy sợi dây khẽ giật, lão hớn hở. "Nó chỉ lượn một vòng thôi mà", lão nói. "Nó sẽ cắn câu." (Lê Huy Bắc, 1998, p.35)

\section{Final position}

It is difficult to find out only in the final position. Consider the example in (9), only in this place is employed to modify an object or complement.

(9) There was just that shadowiness about them which you find in people who lives are part of the social organism, so that they exist in it and by it only. (Maugham, 1996, p.22)

Bạn sẽ tìm thấy cũng chính điều mù mờ đó nơi những người mà cuộc sống là một bộ phận của cơ chế xã hội, họ chỉ tồn tại được trong đó và nhờ đó mà thôi. (Nguyễn Thành Thống, 1987, p. 37)
Table 2. Description of positions of only in the sentences and its Vietnamese equivalents

\begin{tabular}{ccc}
\hline No & $\begin{array}{c}\text { Positions of only } \\
\text { in English }\end{array}$ & $\begin{array}{c}\text { Positions of only in } \\
\text { Vietnamese }\end{array}$ \\
\hline 1 & Initial position & Initial and Medial position \\
2 & Medial position & Medial position \\
\hline 3 & Final position. & Medial position \\
\hline
\end{tabular}

\subsection{Syntactic functions of only in the sentences and its Vietnamese equivalents}

As known that the syntactic categories of words and groups of words are revealed by patterns in sentences. Syntax, basically, studies the structure of well-formed phrases and sentences. In fact, it is important to note that only can function differently in a sentence or instance.

\section{Premodifying a noun phrase}

In the study corpus, there are many instances of only assuming the position of an approximation before a noun phrase. Premodifying a noun or noun phrase seems to be the most frequently used function of only.

(11) There were only three boats in sight now and they showed very slow and far inshore. (Hemingway, 1952, p.24) Giờ đây trong tầm mắt, Chỉ còn lại ba bóng thuyền, man lún sâu xuống nước và ở mãi tít phía trong bờ. (Lê Huy Bắc, 1998, p.29)

From the above examples, it is easy to recognize that only modifies for a noun or a noun phrase, but its functions are different: as a verb in (12), and a noun as in (13). Let us look the following examples:

(12) She could not describe in words the ecstasy; that taste of the Divine love which only the souls of the transplanted could endure in its awful and complete intensity. (Spack, 1994, p.58)

Cô không sao mô tả nổi bằng lời cho được niềm mê ly ngất ngây hương vị của tình thương thiêng liêng mà 
chỉ có tâm hồn của những người đã được hóa chuyển mới có thể chịu đựng được đầy đủ cường độ ghê gớm. (Spack, 1994, p.61)

(13) The clouds over the land now rose like mountains and the coast was only a long green line with the gray blue hills behind it. (Hemingway, 1952,, p.26)

Bây giờ những đám mây trên đất liền đùn lên tựa những quả núi và bờ biển chỉ còn là một vệt xanh dài với rặng xanh thẫm đằng sau nó. (Lê Huy Bắc, 1998, p.30)

Besides this, one of the most interesting meanings of only the author finds out in this part is its equivalents in Vietnamese "chi trù; chẳng qua chỉ là...”. Some typical expressions are presented hereafter:

(14) I wish I was a fish, He thought, with everything he has against only my will and my intelligence. (Hemingway, p.56)

Ước gì ta là con cá, lão nghĩ, với mọi phẩm chất nó có chỉ trừ khát vọng và trí tuệ của ta. (Lê Huy Bắc, 1998, p.50)

(15) This dictum - that Bosinney was chic - caused quite a sensation. It failed to convince that he was goodlooking in a way they were prepared to admit, but that anyone could call a man with his pronounced cheekbones, curious eyes, and soft felt hats chic was only another instance of Winifred's extravagant way of running after something new. (Glasworthy, 1994, p.150)

Lời tuyên bố chính thức này, coi Bôxini là con người lịch sự đúng là đã làm chấn động dư luận. Nói thế không thuyết phục được ai. nếu bảo chàng "có vẻ tốt về một mặt nào đó" thì thiên hạ sẵn sàng chấp nhận, nhưng bất cứ ai có thể gọi con người có lưỡng quyền cao, mắt nhìn tò mò, đội mũ phớt mềm, là lịch sự thì chẳng qua chỉ là một ví dụ khác về cái tính phóng túng của Uyniphorit thích chạy theo cái mới. (Hoàng Túy \& Cảnh Lâm, 1986, p.273)

\section{Premodifying a prepositional phrase}

In formal and literary style, negative adverbials can be used at the beginning of a clause, for example: only by, only in, only with, etc.

(16) I, of course, am there only in the evenings and on weekend. (Spack, 1994, p.117)

Lẽ dĩ nhiên tôi ở đó chỉ vào những buổi tối và những ngày cuối tuần. (Spack, 1994, p.119)

(17) But all the experts were agreed that three commodes could have been executed only by Thomas Chippendale himself. (Cochrane \& Pierce, 1999, p.307)

Nhưng tất cả các chuyên viên giám định đều nhất trí rằng ba bộ tủ ngăn kéo trên có thể do chính Thomas Chippendale thực hiện.... (Mai Khắc Hải \& Mai Khắc Bích, 1994b, p.336)

Hence, it is clear to us that only in the above examples functions as an adverb modifying for the whole sentence. It is noticed that in (16), (17) only is used to emphasize the time.

Premodifying an adjectival or an adverbial phrase

As seen from instances from (18) only functions as an adverb to modify an adjective. Its meaning in Vietnamese equivalents also changes.

(18) "I think it only right" Trudy said in her young way ...." (Cochrane \& Pierce, 1988, p.120)

"Em nghĩ cũng là điều phải lẽ." Trudy nói bằng cách cung cách trẻ trẻ của cô. (Mai Khắc Hải \& Mai Khắc Bích, 1994a, p.141) 
(19) He saw the reflected glare of the lights of the city at what must have been around ten o'clock at night. They were only perceptible at first as the light is in the sky before the moon rises. (Hemingway, 1952, p.109)

Vào khoảng mười giờ tối, lão trông thấy ánh đèn thành phố hắt xuống nước. Thoạt tiên, đấy chỉ là thứ ánh sáng mang mang trên bầu trời như trước lúc mặt trời mọc.

(Lê Huy Bắc, 1998, p.86)

In addition, only modifies an adverb or an adverbial phrase as seen in the following examples:

(20) The archaeologist Gordon R.Willey has argued, only partly in fun. (Alexander, 1993, p.164)

Nhà khảo cổ học Gordon R.Willey đã lập luận, pha chút khôi hài. (Hồ Hải Thụy, Khắc Chu Thuật \& Xuân Cao Phổ, 1999, p.350)

(21) The position actually was only somewhat less intolerable; but he thought of it as almost comfortable. (Hồ Hải Thụy, Khắc Chu Thuật, \& Xuân Cao Phổ, 1999, p.38)

Tư thế ấy thực là cũng chỉ bớt được đôi phần, nhưng lão nghĩ là rất thỏa mái. (Lê Huy Bắc, 1998, p.38)

Premodifying a declarative content, or an imperative clause

Only can premodify a declarative, an interrogative, an exclamative or an imperative clause. Following are typical examples:

(22) It doesn't work. May never have been good. It might be only that the batteries are flat.... (Cochrane \& Pierce, 1999, p.261)

Cái radio hỏng rồi. Có lẽ cũng chẳng ích lợi gì cả. Cũng có thể là chỉ vì pin đã cạn. (Mai Khắc Hải \& Mai Khắc Bích, 1994b, p.281)

(23) We missed you - we've been searching - It was only that Ted saw where you'd walked down the fence.... (Cochrane \& Pierce, 1999, p.269)

Anh đã lạc em - bọn anh đang đi tìm chỉ có Ted nhìn thấy em bước xuống phía dưới hàng rào.... (Mai Khắc Hải \& Mai Khắc Bích, 1994b, p.294)

Only, nevertheless, is used to premodify an imperative clause when the speaker means to emphasize as indicated in (24).

(24) Only disturb me if there's a genuine emergency. (Hồ Hải Thụy, Khắc Chu Thuật, \& Xuân Cao Phổ, 1999, p.986) Chỉ làm phiền tôi nếu có sự cần thiết thật sự. (Hồ Hải Thụy, Khắc Chu Thuật, \& Xuân Cao Phổ, 1999, p.986)

In (25) below, only also premodifies an imperative clause, but it functions as a conjunction.

(25) The eyes didn't liven, but a faint pink stole into her cheeks. "Yes, Paddy, do that. Only make sure he knows not to tell Frank we found out. Perhaps it would ease Frank to think for certain that we don't know" (McCullogh, 1992, p.169).

Mắt Fia vẫn đờ đẫn, nhưng má bà hơi hồng lên rõ rệt. "Phải đấy, Paddy ạ mình viết đi, nhưng cần nói trước với cha để Người đừng lộ ra với Frenk là chúng ta biết hết rồi.

Cứ để cho Frenk tưởng rằng chúng ta không biết gì hết, có lẽ như vậy nó đỡ khổ tâm hơn.” (Phạm Mạnh Hùng, 1980, p.270).

Premodifying a verb, a to-infinitival and a bare infinitival phrase

For most English sentences a crucial part of meaning resides in the verb, the concept expressed by the verb is typically the heart of the propositional content of a sentence.

It is obvious that the pre-verb position of only gives more information to the verb. Following are typical illustrations:

(26) I usually only have one at lunch. (Spack, 1994, p.91) 
Tôi chỉ dùng một món vào bữa trưa thôi. (Spack, 1994, p.94)

(27) It only shows, Mr Harraby- Ribston remarked, how people differ. (Cochrane \& Pierce, 1999, p.220) Điều đó chỉ cho thấy, ông Harraby Ribston nhận xét, con người ta khác nhau như thế nào. (Mai Khắc Hải \& Mai Khắc Bích, 1994b, p.232)

Only appears in front of to in these instance in order to modify an infinitive which is a verbal clause, usually beginning with to, and functions in the range of noun clauses as a modifier or complement.

(28) He rested sitting on the un-stepped mast and sail and tried not to think only to endure. (Hemingway, 1952, p.37)

Lão ngồi nghĩ trên đống cột buồm, cố không nghĩ ngợi điều gì ngoại trù̀ việc chịu đựng. (Lê Huy Bắc, 1998, p.40)

In contrast, only premodifies an infinitive without to called bare infinitive. Look at these examples.

(29) She followed me up, and sat on the edge of my bed while I sat at the desk, secretly on to the bottles. I can only answer that I mean by it my consciousness of myself. (Alexander, 1993, p.208)

Mẹ tôi chạy theo tôi; bà ngồi ở mép Mẹ tôi chạy theo tôi; bà ngồi ở mép giường trong khi tôi ngồi ở bàn viết, len lén khóc trên tờ giấy thấm. Tôi chỉ có thể trả lời rằng theo tôi đó là sự tự ý thức được chính bản thân mình. (Hồ Hải Thụy, Khắc Chu Thuật \& Xuân Cao Phổ, 1999, p.306)

Premodifying a gerund phrase and a present participle phrase

Only can premodify a gerund phrase or a present participial phrase. The following are a number of typical examples in which only premodifies a gerund phrase:

(30) And Trudy was furious with Gwen on these occasions for seeming not to understand that the breathlessness was all part of her only being twentytwo, and excited by the boyfriend. (Cochrane \& Pierce, 1999, p.119) Và...rằng sự hổn hển đó hoàn toàn nằm trong mức tuổi chỉ mới hai mươi tuổi và vì kích động bởi bạn trai của cô. (Mai Khắc Hải \& Mai Khắc Bích, 1994a, p.139)

In the following example, only premodies a present participial phrase.

(31) You should thank God that your son is only leaving now for the front.... (Spack, 1994, p.75)

Ông phải tạ ơi Chúa vì mãi đến ngày nay con ông bà mới phải ra mặt trận.... (Spack, 1994, p.76)

\section{Premodifying a past participle phrase}

More especially, only can also be used as an adverb to modify a past participial phrase.

(32) It was a large oak armchair of a type that he had only seen once before in his life. (Maugham, 1996, p.299)

Đó là một chiếc ghế dựa lớn bằng sồi thuộc một mẫu mà ông chỉ thấy qua được một lần trước đây trong đời. (Maugham, 1996, p.323)

(33) She took the letter out of her bag. Yes, this was the one, you could feel it had only come today and had only been read once. (Cochrane \& Pierce, 1988, p.26)

Bà lấy cái thư trong túi xách ra. Đúng là cái này, bạn có thể cảm nhận là nó chỉ mới đến hôm nay và chỉ đọc qua có một lần. (Mai Khắc Hải \& Mai Khắc Bích, 1994a, p.38)

Only in the following examples conveys rather strange meanings in Vietnamese:

(34) It is said-not broadcast, it is only whispered- that Alberta sees visions. (Spack, 1994, p.59)

Người ta nói-không loan truyền rộng rãi nhưng chỉ rỉ tai nhau là Alberta 
nhìn thấy nhiều ảo mộng. (Spack, 1994, p.61)

(35) "I don't like the neighborhood," said old Jolyon; "a ramshackle lot,"

Young Jolyon replied; "Yes, we're a ramshacklelot."

The silence was now only broken by the sound of the dog Balthasar's scratching. (Glasworthy, 1994, p.66) Lão Jolian nói tiếp:"Cha không thích quang cảnh xung quanh, trông nó tồi tàn, nhếch nhác quá!"”
(36) April 11 April Fool's Day. Many people like to play jokes or tricks on this day. The jokes are for fun only. (Porter, Minicz \& Cross, 1995, p.64)

Mồng một tháng tư là ngày cá tháng tư. Nhiều người thích chọc ghẹo. Những trò đùa này chỉ để vui thôi. (Porter, Minicz \& Cross, 1995, p.65)

The following table summarizes a general description of the positions of only in the sentences and of the equivalents in Vietnamese.

Table 3. Syntactic functions of only and its Vietnamese equivalents

\begin{tabular}{|c|c|}
\hline No & Syntactic functions \\
\hline & $\mathrm{S}+\mathrm{V}(\mathrm{be})+$ only $+\mathrm{N} / \mathrm{N} \mathrm{Ph}$ \\
\hline 1 & Chi phai .....thôi; chi có; chi viêc; chi con lai; chi con; chi trü; châng qua chì là \\
\hline \multirow{3}{*}{2} & Only + Prep phrase + Aux $+S+V$ \\
\hline & Premodityıng a prepositional phrase \\
\hline & Chì khi; chì duy; do; chí...........mà thôi \\
\hline \multirow{3}{*}{3} & $\mathrm{~S}+$ be + only + Adj \\
\hline & Premodifyıng an adjectival phrase \\
\hline & Cüng là, chi, đâyy chi; \\
\hline \multirow{2}{*}{4} & Premodifying an adverbial phrase \\
\hline & Pha chut, cüng chi; \\
\hline \multirow[b]{2}{*}{5} & Premodifying a verb phrase \\
\hline & Chi, chi đê \\
\hline \multirow[b]{2}{*}{6} & Premodifying a declarative content clause \\
\hline & Chì vi, chí có \\
\hline \multirow{3}{*}{7} & Premodifying a gerund phrase \\
\hline & Chi móti, vi chi \\
\hline & Premodifying a to-infinitival phrase \\
\hline \multirow[t]{2}{*}{8} & Ngoại trì; chi khi; chi \\
\hline & Premodifying a bare infinitival phrase \\
\hline 9 & Chì; mà chì \\
\hline \multirow{2}{*}{10} & Premodifying a past participial phrase $\quad S+A u x+$ only $+V_{\text {Past Participle phrase }}$ \\
\hline & Nhung chi; chi còn; chi \\
\hline \multirow{2}{*}{11} & Premodifying a present participial phrase \\
\hline & Premodifving an imnerative clause \\
\hline 12 & chi, nhing \\
\hline 13 & Postmodifying a noun phrase \\
\hline
\end{tabular}

"Vâng chúng con là một lũ tồi tàn, nhếch nhác." Chàng Jolian tả lời.

Giờ đây chỉ còn nghe tiếng cào gãi của con chó Bônđơxa. (Hoàng Túy \& Cảnh Lâm, 1986, p.123)

\section{Postmodifying a noun phrase}

It is evident from the bilingual corpus that only is rarely used in the final position.

\subsection{Similarities and differences in the syntactic} features of only in English and Vietnamese

With respect to the syntactic position, Only in English has initial, medial, final positions in the clause or in the sentences, while its Vietnamese equivalents are found mainly in the initial and medial positions; the final position is not identified in the bilingual corpus. 
As regards the syntactic functions of Only in English and Vietnamese, while only in English and its equivalents in Vietnamese, as in
Table 4, have a number of syntactic features in common, they do have some slight differences.

Table 4. Similarities in the syntactic functions of only in English and its Vietnamese equivalents

\begin{tabular}{|c|c|c|}
\hline No & Syntactic functions & Its Vietnamese equivalents \\
\hline \multirow{4}{*}{1} & Premodifying a noun phrase & ...chi còn lại ba bóng thuyền... \\
\hline & $\mathrm{S}+\mathrm{V}(\mathrm{be})+$ only $+\mathrm{N} / \mathrm{N} \mathrm{Phr}$ & ...chi có tâm hồn... \\
\hline & e.g., There were only three boats... & ...chì trù khát vọng \\
\hline & & ... chẳng qua chỉ là một ví dụ.. \\
\hline \multirow{4}{*}{2} & Premodifying a prepositional phrase & ...chi khi ngồi vào lòng.... \\
\hline & Only + Prep phr + Aux $+S+V$ & ...chỉ vài phút mà thôi... \\
\hline & $\mathrm{S}+\mathrm{V}+$ only + prep phr & ... chi vào những buổi tối... \\
\hline & e.g., I am there only in the evenings... & \\
\hline \multirow{4}{*}{3} & - Premodifying an adjectival phrase & ... cuñng là điều phải lê ... \\
\hline & $\mathrm{S}+$ be + only + Adj & \\
\hline & $\mathrm{S}+\mathrm{V}+\mathrm{it} / \mathrm{O}+$ only + adj & \\
\hline & e.g., I think it only right. & \\
\hline \multirow{4}{*}{4} & Premodifying an adverbial phrase & ...pha chút khôi hài. \\
\hline & $\mathrm{S}+\mathrm{V}+$ only $+\mathrm{Adv}$ & ...cüng chỉ bớt được đôi phần ... \\
\hline & e.g., The archaeologist Gordon R.Willey has & \\
\hline & argued, only partly in fun. & \\
\hline \multirow{3}{*}{5} & Premodifying a verb phrase & ...chi dùng một... \\
\hline & $\mathrm{S}+(\mathrm{Adv})+\mathbf{o n l y}+\mathrm{V}$ & ...chi cho thấy... \\
\hline & e.g., I usually only have one at lunch & ...chỉ để cho lời nói ... \\
\hline \multirow{3}{*}{6} & Premodifying a declarative content clause & ...chi vi pin đã cạn .. \\
\hline & $\mathrm{S}+\mathrm{V} / \mathrm{be}+$ only that + Clause & ...chỉ có Ted nhìn thấy em bước... \\
\hline & e.g., It might be only that the batteries are flat... & \\
\hline \multirow{4}{*}{7} & Premodifying a gerund phrase & ...chi mới hai mươi tuồi... \\
\hline & $\mathrm{S}+\mathrm{V} / \mathrm{be}+\ldots+$ only + Gerund & ...vì chỉ có ba chúng ta... \\
\hline & e.g., The breathlessness was all part of her only & \\
\hline & being twenty-two..... & \\
\hline \multirow[b]{3}{*}{8} & Premodifying a to-infinitival phrase & ...ngoại trü việc chịu đựng... \\
\hline & $\mathrm{S}+\mathrm{V}+$ only + to $-\mathrm{V}$ & ...chi khi nhìn vào đôi tay... \\
\hline & e.g., He tried not to think only to endure... & ... chỉ để giữ mạng sống ... \\
\hline \multirow{3}{*}{9} & Premodifying a bare infinitival phrase & ...chì có thề trả lời. \\
\hline & $\mathrm{S}+$ modal verbs + only $+\mathrm{V}$ & ...mà chi nghe thấy..., \\
\hline & e.g., I can only answer... & \\
\hline \multirow{3}{*}{10} & Premodifying a past participial phrase & ...chi thây qua được một lần... \\
\hline & $\mathrm{S}+$ Aux + only $+\mathrm{V}_{\text {Past Participle phrase }}$ & ...chi mói đến... \\
\hline & e.g., ... it had only come today.... & ... nhung chỉ rỉ tai nhau... \\
\hline \multirow{3}{*}{11} & Premodifving a present particinial phrase & ... chi còn nghe tiếng cào... \\
\hline & $\begin{array}{l}\text { Premoditying a present participial phrase } \\
\mathrm{S}+\text { be }+ \text { only }+\mathrm{V}\end{array}$ & ...mót phai ra mặt trận ... \\
\hline & & \\
\hline \multirow{4}{*}{12} & Premodifying an imperative clause & ...chi làm phiền .. \\
\hline & Only + V + Clause & ...chỉ gọi đội cứu hỏa... \\
\hline & e.g., Only disturb me if there's a genuine & ...nhưng cần nói trước.. \\
\hline & emergency. & \\
\hline \multirow{3}{*}{13} & Postmodifying a noun phrase & chi chịu trách nhiệm về độ cao... \\
\hline & $\mathrm{S}+\mathrm{V}+\mathrm{O} / \mathrm{Comp}+\mathbf{o n l y}$ & ... chỉ hướng dẫn bạn... \\
\hline & e.g., The jokes are for fun only. & ...chi trên một mặt giấy... \\
\hline
\end{tabular}


There are, however, not many differences in syntactic functions of only in English and its equivalents in Vietnamese as seen in Table 5, only in English has thirteen functions, but Vietnamese only has three functions. Here, the prominent point that can be figured out is that its Vietnamese equivalents often premodify a noun phrase, an adjectival phrase and a verb phrase.
Furthermore, Vietnamese EFL learners of English should be exposed to authentic materials in a good language environment to learn only more effectively and to use it more properly.

The discourse marker only, in another aspect, is often considered as a restrictive word; thus it is often translated into Vietnamese as: chỉ, chì là , chỉ có, duy nhất, độc nhất, duy chỉ. It is advisable that translators should pay close

Table 5. Differences in the syntactic functions of only in English and its Vietnamese equivalents

\begin{tabular}{cccc}
\hline No & Syntactic functions of only & In English & In Vietnamese \\
\hline 1 & Premodifying a noun phrase & $\mathbf{x}$ & $\mathbf{x}$ \\
\hdashline 2 & Premodifying a prepositional phrase & $\mathbf{x}$ & $\mathbf{x}$ \\
\hline 3 & Premodifying an adjectival phrase & $\mathbf{x}$ & $\mathbf{x}$ \\
\hline 4 & Premodifying an adverbial phrase & $\mathbf{x}$ & \\
\hline 5 & Premodifying a verb phrase & $\mathbf{x}$ & $\mathbf{x}$ \\
\hline 6 & Premodifying a to-infinitival phrase & $\mathbf{x}$ & \\
\hline 7 & Premodifying a bare infinitival phrase & $\mathbf{x}$ & \\
\hdashline 8 & Premodifying a gerund phrase & $\mathbf{x}$ & \\
\hdashline 9 & Premodifying a declarative content clause & $\mathbf{x}$ & \\
\hdashline 10 & Premodifying a past participial phrase & $\mathbf{x}$ & \\
\hdashline 11 & Premodifying a present participial phrase & $\mathbf{x}$ & \\
\hline 12 & Premodifying an imperative clause & $\mathbf{x}$ & \\
\hdashline 13 & Postmodifying a noun phrase & $\mathbf{x}$ \\
\hline
\end{tabular}

\section{Conclusion}

The discourse marker only, syntactically, is as quite complicated as its various positions are. It, therefore, takes much time for ESL/ EFL learners to identify and learn how to use it. ESL/EFL teachers should clearly point out to their learners which meanings are affected by syntactic features, for instance, teachers may provide students with various instances containing the word only and encourage them to find out its meanings in the given context. Vietnamese EFL teachers should, to help their learners to avoid negative transference, point out the similarities and differences between only in English and its equivalents in Vietnamese. attention the linguistic features of the word only and the given context so as to convey the speaker's/writer's full intention.

\section{References}

\section{English}

Alexander, L. G. (1993). Longman Advanced Grammar. London: Longman.

Arkadiev, P. M. (2010). Notes on Lithuanian Restrictive. Retrieved from http://ling.auf.net/lingbuzz/001061/ current.pdf

Cochrane, E., \& Pierce, T. (Eds.) (1988). 20th Century English Short Stories, Book 1. UK: Nelson ELT.

Cochrane, E., \& Pierce, T. (Eds.) (1999). 20th Century English Short Stories, Book 2. UK: Nelson ELT. 
Dryer, M. S. (1994). The Pragmatics of FocusAssociation with Only, MIT.

Glasworthy, J. (1994). The Man of Property. UK: Wordsworth Classics.

Hemingway, E. (1952). The Old Man and The Sea. New York: Bantam Books.

Junarso, T. (2009). How to Become a Highly Effective Leader: Ten Skills a Leader Must Po s s e s $s$. iUniverse publications.

Matsuoka, K. (2011). Addressing the Syntax/ Semantics/ Pragmatics interface: The Acquisition of the Japanese Additive Particle mo. Retrieved from http://www.bu.edu/bucld/files/2011/05/28matsuoka.pdf

Maugham, W. S. (1996). The Moon and Sixpence. London: Penguin Books.

McCullogh, C. (1992). The Thorn Birds. New York: Harper \& Row Publishers.

Porter. C, Minicz. E, \& Cross. C. (1995). Holidays in the USA (translated Version). Ho Chi Minh City: The Youth Publishing House.

Rooth, M. (1996). Focus. In L. Shalom (Ed), The Handbook of Contemporary Semantic

Theory (pp. 271-297). Cambridge, MA: Blackwell.
Spack, R. (1994). The International Story. New York: ST. Martin's Press.

\section{Vietnamese}

Lê Huy Bắc (1998). Ông Già và Biển Cả. Hà Nội: Nxb Văn học.

Mai Khắc Hải và Mai Khắc Bích (1994a). Nhũng Câu Truyện Ngắn Thế Kỷ 20, tập 1. Đà Nẵng: Nxb Đà Nẵng.*

Mai Khắc Hải và Mai Khắc Bích (1994b). Nhũng Câu Truyện Ngắn Thế Kỷ 20, tập 2. Đà Nẵng: $\mathrm{Nxb}$ Đà Nẵng.

Phạm Mạnh Hùng (1980). Tiếng Chim Hót Trong Bụi Mận Gai. Hà Nội: Nxb Văn học.

Nguyễn Thành Thống (1987). Vầng Trăng và Sáu Xu. Phú Khánh: Nxb tổng hợp Phú Khánh.

Hồ Hải Thụy, Khắc Chu Thuật, và Xuân Cao Phổ (1999). Tù Điển Anh-Việt. Hồ Chí Minh: Nxb Thành Phố Hồ Chí Minh.

Hoàng Túy và Cảnh Lâm (1986). Nguoòi Tur Hũu. Hà Nội: Nxb văn học Hà Nội.

\title{
PHÂN TÍCH ĐặC ĐIỂM CÚ PHÁP CỦA HƯ TỬ ONLY TRONG TIẾNG ANH VÀ TƯƠNG ĐƯƠNG DỊCH THUẬT CỦA NÓ TRONG TIẾNG VIỆT
}

\author{
Trần Quốc Thao ${ }^{1}$, Nguyễn Văn Mười ${ }^{2}$ \\ ${ }^{1}$ Truoòng Đại học Su phạm Kỹ thuật TP. Hồ Chí Minh, \\ Số 1 Võ Văn Ngân, Quận Thủ Đức, TP. Hồ Chi Minh, Việt Nam \\ ${ }^{2}$ Truờng Đại học Buôn Ma Thuột, 298 Hà Huy Tập, Tân An, TP. Buôn Ma Thuột, Việt Nam
}

Tóm tắt: Đây là một nghiên cứu định lượng và miêu tả nhằm tìm hiểu đặc điểm cú pháp của hư từ only trong tiếng Anh và tương đương dịch thuật của nó trong tiếng Việt. Dữ liệu nghiên cứu là tập sao lục song ngữ bao gồm 168 câu tiếng Anh và 168 câu dịch tiếng Việt tương đương. Phương pháp so sánh đối chiếu được dùng để phân tích dữ liệu. Kết quả cho thấy hư từ only trong tiếng Anh thường xuất hiện ở vị trí đầu, giữa và cuối câu, trong khi đó, nó chỉ xuất hiện ở vị trí đầu và giữa câu trong các bản dịch tiếng Việt. Hơn nữa, nghiên cứu này còn tìm thấy có nhiều điểm tương đồng hơn điểm dị biệt về chức năng cú pháp của hư từ only trong tiếng Anh và tiếng Việt.

Từ khóa: so sánh đối chiếu, hư từ only, tiếng Anh, tiếng Việt, đặc điểm cú pháp

\footnotetext{
* Tác giả giữ nguyên tiêu đề của tác phẩm như đã được xuất bản
} 